\title{
Potential of babassu biofuels use as aviation fuel
}

\author{
Potencial do uso de biocombustíveis de babassu como combustível para aviação \\ Potencial del uso de biocombustibles babaçu como combustible de aviación
}

Received: 12/29/2021 | Reviewed: 01/04/2022 | Accept: 01/11/2022| Published: 01/13/2022

\author{
Julio Cezar Girardi \\ ORCID: https://orcid.org/0000-0002-9940-2805 \\ State University of West Parana, Brazil \\ E-mail: juliocgirardi@gmail.com \\ Reinaldo Aparecido Bariccatti \\ ORCID: https://orcid.org/0000-0002-9780-9409 \\ State University of West Parana, Brazil \\ E-mail: bariccatti@yahoo.com.br \\ Samuel Nelson Melegari de Souza \\ ORCID: https://orcid.org/0000-0002-3581-902X \\ State University of West Parana, Brazil \\ E-mail: samuel.souza@unioeste.br \\ Camila Zeni do Amaral \\ ORCID: https://orcid.org/0000-0001-5772-8017 \\ State University of West Parana, Brazil \\ E-mail: camilazamaral@gmail.com \\ Carmen Luisa Barbosa Guedes \\ ORCID: https://orcid.org/0000-0002-8490-7130 \\ State University of Londrina, Brazil \\ E-mail: carmen@uel.br \\ Jonathan Bauni \\ ORCID: https://orcid.org/0000-0002-6315-1522 \\ State University of Londrina, Brazil \\ E-mail: jonathanbaumi@hotmail.com.br \\ Caroline Milani Bertosse \\ ORCID: https://orcid.org/0000-0002-0841-9426 \\ State University of Londrina, Brazil \\ E-mail: carolbertosse@yahoo.com.br
}

\begin{abstract}
Through a review of the bibliographic base was identified the potential and difficulties of using biofuels based on babassu culture for use as aviation biofuel. Babassu palm is one of the most important crops for family farming in the north and northeast of Brazil due to its vast use potential. From babassu oil, by transesterification, good quality biodiesel can be obtained. However, it does not have the properties necessary to be used as aviation biofuel. Researches with biofuels from this culture and cultures with a similar organic profile were analyzed pointing out the feasibility of these biofuels as a mixture in aviation kerosene, nevertheless, these biofuels present several problems when used alone. Among the physical-chemical properties analyzed, the freezing point was a critical factor for not using these biofuels. This review points out the best results to improve the physicochemical properties of babassu biofuels to use as aviation fuel and present an important social factor to this palm uses.
\end{abstract}

Keywords: Bio-jet fuels; Jet fuels; Biofuels; Babassu; Tropic cultures.

\section{Resumo}

Através de uma revisão bibliográfica se avaliou o potencial e as dificuldades do uso de biocombustíveis provindos da cultura do babaçu para uso como biocombustível de aviação. O babaçu é uma das culturas mais importantes para a agricultura familiar no Norte e Nordeste do Brasil devido ao seu vasto potencial de uso. Do óleo de babaçu, por transesterificação, pode-se obter biodiesel de boa qualidade, no entanto, não se possui as propriedades necessárias para ser utilizado como biocombustível de aviação. Pesquisas com os biocombustíveis dessa cultura e com culturas com perfil orgânico semelhante foram analisadas apontando a viabilidade desses biocombustíveis como mistura ao querosene de aviação, no entanto, esses biocombustíveis apresentam diversos problemas quando utilizados isoladamente. Dentre as propriedades físico-químicas analisadas, o ponto de congelamento foi um fator crítico para a não utilização desses biocombustíveis. Esta revisão aponta os melhores métodos e resultados para melhorar as propriedades físico-químicas dos biocombustíveis de babaçu para uso como combustível de aviação e apresenta um importante fator social para o uso dessa palmeira.

Palavras-chave: Biocombustíveis para jato; Biocombustíveis; Babaçu; Culturas tropicais. 


\section{Resumen}

Mediante una revisión de la literatura, se evaluó el potencial y las dificultades del uso de biocombustibles del cultivo de babasú para su uso como biocombustible de aviación. El babasú es uno de los cultivos más importantes para la agricultura familiar en el norte y noreste de Brasil debido a su gran potencial de uso. Se puede obtener biodiésel de buena calidad a partir del aceite de babasú mediante transesterificación, sin embargo, no tiene las propiedades necesarias para ser utilizado como biocombustible de aviación. Se analizaron investigaciones con biocombustibles de este cultivo y con cultivos con perfil orgánico similar señalando la viabilidad de estos biocombustibles en mezcla con queroseno de aviación, sin embargo, estos biocombustibles presentan varios problemas cuando se usan solos. Entre las propiedades fisicoquímicas analizadas, el punto de congelación fue un factor crítico para no utilizar estos biocombustibles. Esta revisión señala los mejores métodos y resultados para mejorar las propiedades fisicoquímicas de los biocombustibles de babasú para su uso como combustible de aviación y presenta un factor social importante para el uso de esta palma.

Palabras clave: Biocombustibles a aviación; Biocombustibles; Babassu; Culturas tropicales.

\section{Introduction}

Concerns about the environmental issue have been growing gradually over the years, especially about greenhouse gas emissions, these emissions are directly linked to the use of fossil fuels (IEA, 2019).

With the growing awareness and technological advances towards sustainability, what is happening gradually, is a replacement from non-renewable sources to more sustainable and ecologically viable sources (Marsh, 2008; Zhang et al., 2016).

Aviation sector is responsible for $2 \%$ of all $\mathrm{CO}_{2}$ emissions produced by human activities and is projected to reach $3.5 \%$ with the increase in this transport activity over the next decades (Cui \& Li, 2017; IATA, 2017). Because of it, some studies are being developed with the purpose to reduce these negative impacts, like improve turbines efficiencies and developments of renewable fuels environmentally friendly (Kandaramath Hari et al., 2015; Wang \& Tao, 2016; Yang et al., 2019).

The development of renewable fuels in the aviation sector still is a piece of very new knowledge, thus, none environmentally suitable fuel can efficiently replace aviation fuel. However, some chemical compounds have been used to make biofuels viable in this area, such as the use of biokerosene, esters, sugars, and alcohols (Cremonez et al., 2015; GutiérrezAntonio et al., 2017; Kandaramath Hari et al., 2015; Yang et al., 2019).

The difficulty in obtaining an aviation biofuel is related to elaborate a fuel that meets the physicochemical standards for this activity, like appropriate flow properties, suitable oxidation stability, right specific mass, satisfactory viscosity, and calorific power required to aeronautical demand (Bergthorson \& Thomson, 2015; Kandaramath Hari et al., 2015; Nie et al., 2019).

Several studies have used low molecular weight biodiesel to make possible the use of these as aviation biofuels, among the most common is the use of jatropha, palm, camellia (Baroutian et al., 2013; Choi et al., 2018; Lin et al., 2020; Ranucci et al., 2018; Rodrigues Ranucci et al., 2014). These biodiesels have characteristics like density and viscosity similar to traditional aviation fuel (Blakey et al., 2011; Ranucci et al., 2018).

Babassu oil is predominantly compound by lauric acid (C12: 0), which facilitates transesterification reaction, because of the short carbon chain, which results in more effective interaction with alcohol. The biodiesel obtained in the babassu oil transesterification has a low molecular weight, few double bonds, and low viscosity (F. C. Silva A \& Cavalcante A, B , H. C. Louzeiro A, B , K. R. M. Moura A , A. P. Maciel A , L. E. B. Soledade B, 2010; Santos et al., 2007). Jet A-1, the traditional fuel used as aviation fuel, it is composed predominantly of 8 to 16 carbons. Because of the organic similarity and the low weight and viscosity of babassu biodiesel, presupposes this biodiesel can be a potential substitute to Jet A-1.

Although having conditions such as density, viscosity and organic components similar to the traditional fuel used in aviation, babassu biodiesel has a high freezing point, which prevents be used in cold places, especially in high altitudes. 
From this context, the objective of this study is to carry out an evaluation of the use of babassu biodiesel as biofuel for aviation, presenting a comparison with traditional aviation fuel and other aviation biofuels.

\section{Methodology}

This study was carried out through a bibliographic survey aiming to identify the potential of biofuels from babassu for use in aero engines.

For this, information was collected on the market, production potential, physicochemical characteristics of babassu oil and biofuels, market and difficulties of aviation biofuels, and a comparison was made between the properties of babassu biofuels obtained in the literature with the quality standard for the Jet A1 aviation fuel.

\section{Babassu biodiesel}

\subsection{Market and production potential of babassu oil in Brazil}

The babassu palm (Orbignya phalerata, Mart.) is one of the most important palm trees in the north and northeast Brazilian regions and, widely, it is found around the south of the Amazon Basin, in the Maranhão, Piauí, and the Tocantins states (Bergmann et al., 2013). Lima et al., 2007 estimates that in the Brazilian Northeast there are about 12 million hectares planted with babassu, being the majority in the Maranhão state.

Although it can be used in the food industry, babassu oil is not traditionally used for this purpose, since the commercial interest for this palm is the use of its wood and straw in the manufacture of handicrafts (Bergmann et al., 2013).

From babassu seed, it is possible to extract an oil that has a transparent yellow color, with a predominantly saturated fatty acid composition. Babassu coconut has an average of $7 \%$ almonds, from which contain about $65 \%$ of oil (Bergmann et al., 2013; L. E. Oliveira et al., 2013).

The incentive to use biodiesel as a fuel source in Brazil, it is not only an environmental issue but also an economic and social development source, as advocated by the biodiesel development program, the National Biodiesel Production and Use Program (PNPB) (Zalla et al., 2019). This incentive program to biodiesel production has basic objectives, among them: social development, job creation, and income distribution to family farmers. By incorporating another source of income for babassu, we are directly contributing to the PNPB objectives, since the extraction activity of this palm, is already included in the reality of farming families in the north and northeast regions (dos Santos Alves et al., 2017).

Since 2008, the main raw materials for the production of commercial biodiesel in Brazil are soybean oil and animal fat. However, there is an increase in the use of other raw materials over the years, increasing from $1 \%$ in 2015 to $12 \%$ in April/2019. This fact represents a market opening for incorporating new sources of raw materials in this sector (ANP/ABIOVE - Coordenadoria de Economia e Estatística, 2019).

The diversification of raw materials guarantees safety in the production of biodiesel, however, despite the increasing diversification of raw materials Brazil still uses primarily first-generation crops, like soybean and corn (ProcessamentoMaterias-Primas-2019(1), n.d.).

\subsection{Physical-Chemical characteristics of babassu oil and biofuels}

Babassu oil is composed of saturated and unsaturated fatty acids, with the predominance of lauric acid (C12:0). This facilitates the transesterification reaction, since the short carbon chain results in more effective interaction with alcohol, obtaining biodiesel with physicochemical characteristics appropriate to current regulations (Lima et al., 2007; Zalla et al., 2019). 
Babassu biodiesel has low molecular weight and few double bonds, which cause low viscosity. Although it shows good quality biodiesel, there are few studies with babassu, nevertheless, the problems related to the use of this biodiesel are similar to those found in short carbon chain biodiesels, such as palm and jatropha (Verma \& Sharma, 2016).

Table 1 shows the chemical composition of fatty acids present in biofuels derived from babassu oil with predominance of $\mathrm{C} 12, \mathrm{C} 14, \mathrm{C} 16$, and C18:1.

Table 1 - Chemical composition of fatty acids presents in babassu biofuels.

\begin{tabular}{|c|c|c|c|c|c|c|c|c|}
\hline & $\begin{array}{l}\text { (Silva et } \\
\text { al., 2011) }\end{array}$ & $\begin{array}{c}\text { (Santos, J. R. De J; } \\
\text { Souza, A. G. De; } \\
\text { Silva, 2008) }\end{array}$ & $\begin{array}{l}\text { (Llamas, Al-Lal, } \\
\text { et al., 2012) }\end{array}$ & $\begin{array}{l}\text { (Da Rós et } \\
\text { al., 2014) }\end{array}$ & \multicolumn{2}{|c|}{ (Ranucci et al., 2018) } & $\begin{array}{l}\text { (V. F. de } \\
\text { Oliveira et } \\
\text { al., 2018) }\end{array}$ & $\begin{array}{l}\text { (V. F. de } \\
\text { Oliveira et } \\
\text { al., 2020) }\end{array}$ \\
\hline & Biodiesel & Biodiesel & Biokerosene & Biodiesel & Biodiesel & Biokerosene & Biodiesel & Biodiesel \\
\hline C8:0/\% Caprylic & 6.40 & 6,8 & 13.27 & 4.54 & 2.15 & 4.08 & 6.76 & 3.79 \\
\hline C10:0/\% Capric & 6.85 & 6,3 & 11.27 & 4.25 & 2.37 & 6.11 & 5.66 & 5.42 \\
\hline C12:0/\% Lauric & 37.57 & 41 & 69.26 & 44.14 & 35.76 & 55.96 & 45.41 & 47.75 \\
\hline C14:0/\% Myristic & 18.63 & 16,2 & 5.58 & 14.47 & 13.40 & 6.57 & 16.51 & 16.54 \\
\hline C16:0/\% Palmitic & 14.39 & 9,4 & 0.61 & 9.38 & 7.93 & 1.66 & 8.68 & 8.58 \\
\hline C18:0/\% Stearic & 8.12 & 3,4 & - & 4.40 & 2.27 & - & & 3.45 \\
\hline C18:1n-9/\% Oleic & 18.46 & 14,2 & - & 14.04 & 15.03 & 3.18 & 13.73 & 12.0 \\
\hline $\begin{array}{c}\text { C18:2n-6/\% } \\
\text { Linoleic }\end{array}$ & 2.34 & 2,5 & - & 2.83 & 2.62 & - & 13.13 & 2.46 \\
\hline
\end{tabular}

Source: Authors.

\section{Bio jet fuel: Review}

\subsection{Current market scenario for aviation biofuels}

Simões and Schaeffer (2005) reported that Brazil has already used blends between biodiesel and aviation kerosene since 1982, with a jet fuel named PROSCENE, that has $10 \%$ of biodiesel in aviation kerosene, and the first flight using this fuel occurred in 1984 with the collaboration of Federal University of Ceará (UFC) and the Brazilian Air Force Command.

In 2008, aviation biofuels were tested in commercial aviation, in which case Air New Zealand used the Boeing 747 with a mixture of 50\% commercial aviation fuel and 50\% jatropha biodiesel. In 2009, both Continental Airlines and Japan Airlines tested fuel blends as energy alternatives. For Continental Airlines, the mixture tested used aviation kerosene, jatropha biodiesel, and algae biodiesel, meanwhile, the mixture tested by Japan Airlines used 50\% of biodiesels from seaweed, camelina, herb, and jatropha, and 50\% of commercial aviation fuel. In both tests, biofuels perform well, allowing a $60 \%$ and 80\% reduction in greenhouse gases (Filimonau \& Högström, 2017).

With the growing demand for biofuels in Brazilian aviation, in 2010 the Brazilian Alliance for Aviation Biofuels (ABRABA) was created, a group with the largest companies related to the aviation sector and biofuel production, to the goal of reducing the dependence on fossil fuels and guarantee supply and competition in this sector (Biocombustiveis Aeronáuticos Progressos e Desafios, 2010; Cremonez et al., 2015).

Over the years, tests with biofuels blends with aviation fuel had been intensified, search for reducing the emission of greenhouse gases. In 2014, on the flight accomplished by KLM Royal Dutch Airlines, was used commercial aviation fuel with a blend of $20 \%$ of the reused frying oil, and, it was possible to make the 10-hour flight, between Amsterdam and Aruba, without any inconvenience or failure (BIODIESELBR, 2014). Table 2 shows the main flights performed with aviation biofuels using different biomass. 
Table 2 - Main flights performed using biofuels from different biomass.

\begin{tabular}{|c|c|c|c|c|c|c|}
\hline Flight Type & Location & Airlines & Aircrafts & Raw material & Biojet Fuel \% & Year \\
\hline Commercial & Shanghai-Beijin & Hainan Airlines & Boeing 747-800 & Used cooking oil & 50 & 2015 \\
\hline Commercial & Shanghai-Hong Kong & Dragonair & Airbus A330-300 & Used cooking oil & 50 & 2015 \\
\hline Commercial & $\begin{array}{l}360 \text { flights during the } \\
\text { FIFA WorldCup } 2014 \\
\text { Rio de Janeiro }\end{array}$ & $\begin{array}{c}\text { Gol Transportes } \\
\text { Aéreos }\end{array}$ & Boeing 737-700 & $\begin{array}{l}\text { Inedible corn oil and used } \\
\text { cooking oil }\end{array}$ & 4 & 2014 \\
\hline Commercial & Bogota-Calí & $\begin{array}{l}\text { LAN } \\
\text { National }\end{array}$ & Airbus A320 & Camelina oil & 30 & 2013 \\
\hline Test & Ontario & $\begin{array}{l}\text { Research Council } \\
\text { of Canada(NRC) }\end{array}$ & Falcon 20 & Brassica carinata oil & 100 & 2012 \\
\hline Commercial & Mexico City-São Paulo & Aeroméxico & Boeing 777-200 & $\begin{array}{c}\text { Used cooking oil (44\%), } \\
\text { Jatropha oil (1\%)and Camelina } \\
\text { oil (5\%) }\end{array}$ & 50 & 2012 \\
\hline Commercial & Hamburg to Frankfurt & Lufthansa & Airbus A321 & Jatropha/camelina/animal fat & 50 & 2011 \\
\hline Commercial & Rio de Janeiro & TAM & Airbus 320 & Jatropha oil & 50 & 2010 \\
\hline Test & London-Amsterdam & Virgin Atlantic & Boeing747-400 & Coconut and Babassu & 20 & 2008 \\
\hline
\end{tabular}

Source: Adapted from (Cremonez et al., 2015; Gonçalves F dos R, Borges LEP, 2011; Gutiérrez-Antonio et al., 2017).

In the flights carried out in 2015, highlight the flights of Hainan Airlines, which used the technology of hydroprocessing of esters and fatty acids from cooking oil in commercial aviation using the Boeing 747. Thus, it is demonstrated that in addition to the use of more suitable biomasses to biojet fuel production, biofuel processing, and production routes are of extreme importance for the final quality of the fuel. And, currently, the companies that are leaders in biofuels production, such as UOP Honeywell, SkyNRG, and Sasol, have been investing to optimize their production to bring greater sustainability and economic viability to biofuels (Gutiérrez-Antonio et al., 2017; Olcay H, Malina R, Upadhye AA, Hileman JI, Huber GW, 2018; Zhang et al., 2016).

Currently, aviation fuels must meet extremely restrict specifications before being used in their activities. The technical standards ASTM D1655, of the American Society for Tests and Materials, and DEF STAN 91-91 of the British Ministry of Defense (MOD), are the two specifications used to ensure the properties of aviation fuels. As for aviation biofuels, these are defined by the standards, as mixtures between conventional aviation fuel and renewable fuels, and bio-based synthetic hydrocarbons, not necessarily being 100\% bio-based compounds. However, the aviation biofuels must meet specifications similar to the ASTM D1655 standard, to be compatible with the existing aircraft fleet (Blakey et al., 2011; Wilson et al., 2013; Zhang et al., 2016). In 2009, the American company ASTM, and the British organization DEF STAN, defined the specification standard for turbine fuel with hydrocarbons synthesized through the ASTM D7566 standard (Zhang et al., 2016).

In Brazil, until the year 2019, was followed the international standard rules for aviation biofuels, but recently the Brazilian Agency for petroleum, natural gas, and biofuels (ANP), created resolution ANP n ${ }^{\circ}$ 778/2019 which specifies the quality obligations of aviation kerosene, alternative aviation kerosene, and $\mathrm{C}$ aviation kerosene (blend among bio-kerosene and Jet-A1) (ANP, 2019).

The study by Llamas et al. (2012b) demonstrated that the blend between coconut and palm biodiesel can be mixed with Jet-A1 fuel in a volume of up to $10 \%$ and still meet the specifications of the current legislation, thus shows the feasibility of using biofuels in aeronautical sector cooperating for the development of technologies better suited to the environment.

Baroutian et al. (2013) also observed in a similar study, that a blend among jatropha biodiesel and residual oils can be added to the Jet-A1, being a better alternative, and more environmentally friendly than just the use of fossil fuel.

Ranucci et al. (2018), found that the use of biodiesel from jatropha, babassu, and palm in blends with the Jet-A1, with combinations until 10\%, meet the standards imposed by the American norm. And the blends with $20 \%$, only the standard of 
calorific value was not met, being in a lower margin of only $0.3 \mathrm{MJ} . \mathrm{Kg}$. Thus, it is possible to verify the feasibility of using these partial blends with fossil fuel, reducing consumption and the impacts of this use.

\subsection{Difficulty and restrictions on the use of aviation biofuels}

Biokerosene is the most popular biofuel used in aviation, a contributing fact is that the use of this biofuel doesn't require any structural changes in the aeronautical engine. However, its uses are limited for many reasons, among them the fact that this aviation biofuel has a lower energy density compared to the traditional aeronautical fuels (Chuck \& Donnelly, 2014; Schäfer \& Waitz, 2014).

Other disadvantages of renewable fuels to the aviation sector, are related to biodegradability, and the presence of unsaturated fatty acids, whit, usually, provides low oxidative stability and emulsion formation (Atmanli, 2016; Yilmaz \& Morton, 2011). The elevated freezing point is also a serious problem, especially in high altitudes flights (Hajjari et al., 2017; Mahmudul et al., 2017).

Mcgrath et al. (2016) (Mcgrath et al., 2016) cited that, to guarantee the feasibility of using biofuels in aviation, one should try to follow the premises of using non-edible and environmentally adequate raw materials for their productions, and ensure that their fuel characteristics are safe and adequate to international standards. However, to achieve the jet fuel characteristics, these biofuels must pass to additional processes, which would increase their production cost (Liu et al., 2013; Reimer \& Zheng, 2016).

Most of the renewable fuels tested in the aviation sector does not meet the performance and safety standards necessary to aviation fuels, due to its poor combustible characteristics. However, these can be used as blends in traditional jet fuel (Wang \& Tao, 2016).

In 2014, ASTM approved the use of $5 \mathrm{mg} / \mathrm{kg}$ of biokerosene in aviation fuels, once several tests have demonstrated the feasibility of blending jet fuels with the biokerosene, mainly with cultures such as jatropha, algae, and camelina (Baroutian et al., 2013; International Air Transport Association (IATA), 2015; Llamas, Al-Lal, et al., 2012).

In the European renewable energy directive, in 2009, biofuels for aviation uses were mentioned, but at the time, they were a limited technology. The uncertainties about the policies to be adopted also hindered the development of these biofuels, the limitations in the production of first-generation biofuels were views as barriers to aviation biofuels development (P. Deane et al., 2015).

Currently, the European aviation biofuel policy has multiple areas related to its energy and climate policies, in addition to an extensive range of strategies and similar proposals. Therefore, Deane and Pye (2018) (J. P. Deane \& Pye, 2018) recommend that aviation biofuel be integrated strategies into bioeconomy, circular economy, and aviation sectors so that their greater cohesion and better development in these sectors.

To guarantee the use of aeronautical biofuels, in the current and future market scenario, some premises should be followed, as such as: Meet the current fuel standards, like high energy density, and low freezing point; Guide the development of biofuels in ecologically appropriate processes, ensuring a low environmental impact in their production chain, and mitigating the emission of greenhouse gases; Ensure economic competitiveness with fossil fuels; To avoid the use of firstgeneration raw materials (Biocombustiveis Aeronáuticos Progressos e Desafios, 2010).

Although aviation biofuels use is limited by its poor fuel properties, the options to this will increase as the properties of these alternative fuels improves. Thus, production technologies should be encouraged to find more sustainable and economically viable aviation fuels (Yilmaz \& Atmanli, 2017). 


\section{Comparison between babassu biofuels and Jet - A1}

Brazil has two main resolutions that define the quality standards for aviation fuels, ANP no 778/2019 (ANP, 2019), which determine standards for aviation kerosene (Jet - A1). And ANP resolution 05/2009 ( $\mathrm{N}^{\circ}$ \& Dou, 2009), which defines the specifications of aviation gasoline.

Both fuels, Jet - A1 and aviation gasoline, are derived from the petro-oil refining process, but the Jet A-1 has 11 and 12 carbons, while the aviation gasoline has 5 to 8 carbons. Consequently, their properties and applications are different too, the Jet A-1 is used in turbine engines, and aviation gasoline in spark-ignition engines, which are small planes (Lu et al., 2020).

Babassu biodiesel is predominantly composed of lauric acid (C12:0) similar to the carbon chain present in Jet - A1, furthermore, it has low viscosity and low density concerning other biodiesels, it makes it a potential alternative for use as aviation biofuel. Table 3 shows a physical-chemical comparison between Jet - A1 and babassu biofuel.

Table 3 - Physical-chemical comparison between Jet - A1 and babassu biofuels.

\begin{tabular}{|c|c|c|c|c|c|c|c|c|c|}
\hline & $\begin{array}{l}\text { (Santos, J. R. De J; } \\
\text { SOUZA, A. G. De; } \\
\text { SILVA, 2008) }\end{array}$ & $\begin{array}{l}\text { (Llamas, Al- } \\
\text { Lal, et al., } \\
\text { 2012) }\end{array}$ & $\begin{array}{l}\text { (Da Rós et } \\
\text { al., 2014) }\end{array}$ & (Ranucci & et al., 2018) & $\begin{array}{l}\text { (V. F. de } \\
\text { Oliveira et } \\
\text { al., 2018) }\end{array}$ & $\begin{array}{l}\text { (Girardi et } \\
\text { al., 2021) }\end{array}$ & $\begin{array}{l}\text { (V.F. de } \\
\text { Oliveira et } \\
\text { al., 2020) }\end{array}$ & Jet A1 \\
\hline $\begin{array}{l}\text { Method / process } \\
\text { / technique }\end{array}$ & Biodiesel & Biokerosene & Biodiesel & Biodiesel & Biokerosene & Biokerosene & $\begin{array}{l}\text { Biodiesel } \\
\text { with } \\
\text { additives }\end{array}$ & $\begin{array}{c}\text { Biodiesel } \\
\text { Fatty Acids }\end{array}$ & $\begin{array}{l}\text { ASTM } \\
\text { D7566 }\end{array}$ \\
\hline Organic Profile & Table 1 & Table 1 & Table 1 & Table 1 & Table 1 & Table 1 & - & Table 1 & - \\
\hline Color and aspect & - & Clear & - & - & - & - & Clear & - & Clear \\
\hline Density $\left(\mathrm{kg} / \mathrm{m}^{3}\right)$ & $877.8^{\mathrm{a}}$ & $874.5^{\mathrm{b}}$ & $870.0 \mathrm{a}$ & $871.5^{\mathrm{a}}$ & $870.1^{\mathrm{a}}$ & $875^{\mathrm{b}}$ & $827-903^{a}$ & $861-872^{b}$ & $\begin{array}{l}775- \\
840^{\mathrm{b}}\end{array}$ \\
\hline $\begin{array}{l}\text { Viscosity at } 40 \\
{ }^{\circ} \mathrm{C}\left(\mathrm{mm}^{2} / \mathrm{s}\right)\end{array}$ & 3.07 & 2,15 & 4.2 & 4.86 & 3.81 & 2.6 & $3.4-3.9$ & $2.8-5.6$ & $8, \max$ \\
\hline $\begin{array}{l}\text { Heating value } \\
(\mathrm{MJ} / \mathrm{kg})\end{array}$ & - & $34.93-37.41$ & - & 38.107 & 36.750 & 38.1 & - & $37.8-40.5$ & $\begin{array}{l}42.8, \\
\min \end{array}$ \\
\hline Flash point & 116 & 50 & - & 48 & 48 & - & - & - & $38, \min$ \\
\hline Cloud point $\left({ }^{\circ} \mathrm{C}\right)$ & -3 & -7 & - & - & - & - & 1 to -12 & -4 to -26 & -47 \\
\hline Pour point $\left({ }^{\circ} \mathrm{C}\right)$ & - & -23 & $-8,5$ & - & - & -10 & -9 to -13 & -6 to -27 & -47 \\
\hline $\begin{array}{c}\text { Oxidative } \\
\text { stability (h) }\end{array}$ & $>6$ & $>8$ & - & - & - & - & - & - & - \\
\hline
\end{tabular}

${ }^{\text {a }}$ Specific mass at $20^{\circ} \mathrm{C} ;{ }^{\text {b }}$ Specific mass at $15^{\circ} \mathrm{C}$. Source: Authors.

Although babassu biodiesel has similarities in physical and chemical properties to Jet - A1, the most discrepant factors are related to the freezing properties as could point, pour point and cold filter plugging point.

These characteristics are linked to the crystallization of molecules present in biodiesel. And the crystallization depends on the molecular packaging, and the interaction between the molecules, therefore, factors such as molecular weight, ramifications, and the presence of polar groups in carbon chains, have effects on these properties (Knothe \& Dunn, 2009; Rodrigues et al., 2006).

Santos, Souza, and Silva (2008) points out that babassu biodiesel has a freezing point of $-3^{\circ} \mathrm{C}$, in the study by (Silva et al., 2011) babassu biodiesel through transesterification by ethyl route obtained the freezing point around $-8^{\circ} \mathrm{C}$. Thus, despite having viability in tropical conditions, its freezing properties make its use as aviation fuel unfeasible, so it is necessary to bring innovative ways to improve this condition.

It is possible to analyze that when a more detailed treatment is carried out, such as in the researches by Llamas et al. (2012a), and Ranucci et al. (2018), a better quality biofuel is obtained. However, the biofuels produced in the studies do not have the physical-chemical specifications identical to the Jet-A1. 
(V. F. de Oliveira et al., 2020) obtained promising results in the freezing properties by using C1-C8 alcohols to obtained fatty acid alkyl esters from babassu oil. Consideration the physical and chemical aspects of the biofuel obtained by Oliveira's study has great potential as biojet fuel or as blend in Jet-A1.

Thus, to make feasible this fuel, methods of improving the heating value and decreasing the density and freezing point must be sought. An alternative for it would be the use of additives that upgrade these characteristics (Ali et al., 2013; Imtenan et al., 2015; Monirul et al., 2017).

\section{Final Considerations}

Babassu biofuels has potential to use as aviation biofuels, mainly by performing previous treatments to their production. These conditions may increase the price of the final fuel, but they are more socially and ecologically viable options.

The babassu biofuels is an important alternative to aviation biofuel sector specially in Brazilian market, once it physicalchemical had similarities to the Jet-A1. However, researches with this biofuel and with blends between this biofuel and aviation fuel is still necessary to make its use feasible.

Considering the focus on technical development of aviation biofuels, studies are suggested to improve the physicochemical conditions of babassu biofuels, mainly the freezing properties, and study with tests of babassu biofuels in aeromotors.

\section{References}

Ali, O. M., Mamat, R., \& Faizal, C. K. M. (2013). Review of the effects of additives on biodiesel properties, performance, and emission features. Journal of Renewable and Sustainable Energy, 5(1). https://doi.org/10.1063/1.4792846

ANP/ABIOVE - Coordenadoria de Economia e Estatística. (2019). Produção de biodiesel por matéria-prima - 01/2008 - 04/2019. http://abiove.org.br/estatisticas/biodiesel-producao-por-tipo-de-materia-prima/

ANP. (2019). Resolution $n^{\circ} 778$ of April 05. National Agency of Petroleum, Natural Gas and Biofuels. http://legislacao.anp.gov.br/?path=legislacao-anp/resolanp/2019/abril\&item=ranp-778-2019\&export=pdf

Atmanli, A. (2016). Comparative analyses of diesel-waste oil biodiesel and propanol, n-butanol or 1-pentanol blends in a diesel engine. Fuel, 176, 209-215. https://doi.org/10.1016/j.fuel.2016.02.076

Baroutian, S., Aroua, M. K., Raman, A. A. A., Shafie, A., Ismail, R. A., \& Hamdan, H. (2013). Blended aviation biofuel from esterified Jatropha curcas and waste vegetable oils. Journal of the Taiwan Institute of Chemical Engineers, 44(6), 911-916. https://doi.org/10.1016/j.jtice.2013.02.007

Bergmann, J. C., Tupinambá, D. D., Costa, O. Y. A., Almeida, J. R. M., Barreto, C. C., \& Quirino, B. F. (2013). Biodiesel production in Brazil and alternative biomass feedstocks. Renewable and Sustainable Energy Reviews, 21, 411-420. https://doi.org/10.1016/j.rser.2012.12.058

Bergthorson, J. M., \& Thomson, M. J. (2015). A review of the combustion and emissions properties of advanced transportation biofuels and their impact on existing and future engines. Renewable and Sustainable Energy Reviews, 42, 1393-1417. https://doi.org/10.1016/j.rser.2014.10.034

Biocombustíveis aeronáuticos Progressos e desafios. (2010).

BIODIESELBR. (2014). Realizado voo transatlântico usando bioQAV de óleo de https://www.biodieselbr.com/noticias/biocombustivel/bioqav/realizado-voo-transatlantico-bioqav-oleo-cozinha-190514

Blakey, S., Rye, L., \& Wilson, C. W. (2011). Aviation gas turbine alternative fuels: A review. Proceedings of the Combustion Institute, 33(2), 2863-2885. https://doi.org/10.1016/j.proci.2010.09.011

Choi, I. H., Lee, J. S., Kim, C. U., Kim, T. W., Lee, K. Y., \& Hwang, K. R. (2018). Production of bio-jet fuel range alkanes from catalytic deoxygenation of Jatropha fatty acids on a WOx/Pt/TiO2 catalyst. Fuel, 215(December 2017), 675-685. https://doi.org/10.1016/j.fuel.2017.11.094

Chuck, C. J., \& Donnelly, J. (2014). The compatibility of potential bioderived fuels with Jet A-1 aviation kerosene. APPLIED ENERGY, 118, 83-91. https://doi.org/10.1016/j.apenergy.2013.12.019

Cremonez, P. A., Feroldi, M., De Araújo, A. V., Negreiros Borges, M., Weiser Meier, T., Feiden, A., \& Gustavo Teleken, J. (2015). Biofuels in Brazilian aviation: Current scenario and prospects. In Renewable and Sustainable Energy Reviews (Vol. 43, pp. 1063-1072). Elsevier Ltd. https://doi.org/10.1016/j.rser.2014.11.097

Cui, Q., \& Li, Y. (2017). Will airline efficiency be affected by “Carbon Neutral Growth from 2020" strategy? Evidences from 29 international airlines. Journal of Cleaner Production, 164(2017), 1289-1300. https://doi.org/10.1016/j.jclepro.2017.07.059 
Rós, P. C. M., Silva, W. C. e., Grabauskas, D., Perez, V. H., \& de Castro, H. F. (2014). Biodiesel from babassu oil: Characterization of the product obtained by enzymatic route accelerated by microwave irradiation. Industrial Crops and Products, 52, 313-320. https://doi.org/10.1016/j.indcrop.2013.11.013

Oliveira, V. F., Parente, E. J. S., Cavalcante, C. L., \& Luna, F. M. T. (2018). Short-chain esters enriched biofuel obtained from vegetable oil using molecular distillation. Canadian Journal of Chemical Engineering, 96(5), 1071-1078. https://doi.org/10.1002/cjce.23044

Oliveira, V. F., Parente, E. J. S., Manrique-Rueda, E. D., Cavalcante, C. L., \& Luna, F. M. T. (2020). Fatty acid alkyl esters obtained from babassu oil using C1-C8 alcohols and process integration into a typical biodiesel plant. Chemical Engineering Research and Design, 160, 224-232. https://doi.org/10.1016/j.cherd.2020.05.028

Deane, J. P., \& Pye, S. (2018). Europe's ambition for biofuels in aviation - A strategic review of challenges and opportunities. Energy Strategy Reviews, 20(October 2017), 1-5. https://doi.org/10.1016/j.esr.2017.12.008

Deane, P., O Shea, R., \& Ó Gallachóir, B. (2015). Biofuels for Aviation. Framework Program for Research and Technological Development, April. http://www.innoenergy.com/wp-content/uploads/2016/03/RREB_Biofuels_in_Aviation_Draft_Final.pdf

dos Santos Alves, C. E., Belarmino, L. C., \& Padula, A. D. (2017). Feedstock diversification for biodiesel production in Brazil: Using the Policy Analysis Matrix (PAM) to evaluate the impact of the PNPB and the economic competitiveness of alternative oilseeds. Energy Policy, 109(July), 297-309. https://doi.org/10.1016/j.enpol.2017.07.009

F. C. Silva A, K. S. B., \& Cavalcante A, B , H. C. Louzeiro A, B , K. R. M. Moura A , A. P. Maciel A , L. E. B. Soledade B, A. G. S. B. (2010). Production of biodiesel from babassu oil using methanol-ethanol blends. Ecletica Quimica, 35(1), 47-54. https://doi.org/10.1590/S0100-46702010000100006

Filimonau, V., \& Högström, M. (2017). The attitudes of UK tourists to the use of biofuels in civil aviation: An exploratory study. Journal of Air Transport Management, 63, 84-94. https://doi.org/10.1016/j.jairtraman.2017.06.002

Girardi, J. C., Bariccatti, R. A., de Souza, S. N. M., Amaral, C. Z. do, \& Guedes, C. L. B. (2021). Natural compounds as antifreeze additives to improve babassu biodiesel. Fuel, 289(October), 119746. https://doi.org/10.1016/j.fuel.2020.119746

Gonçalves F dos R, Borges LEP, F. M. (2011). Aviation fuels:perspectives and Future.

Gutiérrez-Antonio, C., Gómez-Castro, F. I., de Lira-Flores, J. A., \& Hernández, S. (2017). A review on the production processes of renewable jet fuel. Renewable and Sustainable Energy Reviews, 79(May), 709-729. https://doi.org/10.1016/j.rser.2017.05.108

Hajjari, M., Tabatabaei, M., Aghbashlo, M., \& Ghanavati, H. (2017). A review on the prospects of sustainable biodiesel production : A global scenario with an emphasis on waste-oil biodiesel utilization. Renewable and Sustainable Energy Reviews, 72(January), 445-464. https://doi.org/10.1016/j.rser.2017.01.034

IATA. (2017). Aviation Benefits 2017. International Air Transport Association, 68. https://doi.org/10.1111/j.1525-1594.2009.00929.x

IEA. (2019). world energy balances: overview (2019 edition). in international energy agency (Vol. 53, Issue 9). https://doi.org/10.1017/CBO9781107415324.004

Imtenan, S., Masjuki, H. H., Varman, M., Rizwanul Fattah, I. M., Sajjad, H., \& Arbab, M. I. (2015). Effect of n-butanol and diethyl ether as oxygenated additives on combustion-emission-performance characteristics of a multiple cylinder diesel engine fuelled with diesel-jatropha biodiesel blend. Energy Conversion and Management, 94, 84-94. https://doi.org/10.1016/j.enconman.2015.01.047

International Air Transport Association (IATA). (2015). Guidance Material for Sustainable Aviation Fuel Management (2nd Editio). https://www.iata.org/contentassets/d13875e9ed784f75bac90f000760e998/iata20guidance20material20for20saf.pdf

Kandaramath Hari, T., Yaakob, Z., \& Binitha, N. N. (2015). Aviation biofuel from renewable resources: Routes, opportunities and challenges. In Renewable and Sustainable Energy Reviews (Vol. 42, pp. 1234-1244). Elsevier Ltd. https://doi.org/10.1016/j.rser.2014.10.095

Knothe, G., \& Dunn, R. O. (2009). A Comprehensive Evaluation of the Melting Points of Fatty Acids and Esters Determined by Differential Scanning Calorimetry. JAOCS, Journal of the American Oil Chemists' Society, 86(9), 843-856. https://doi.org/10.1007/s11746-009-1423-2

Lima, J. R. D. O., Da Silva, R. B., Da Silva, C. C. M., Dos Santos, L. S. S., Dos Santos, J. R., Moura, E. M., \& De Moura, C. V. R. (2007). Biodiesel de babaçu (Orbignya sp.) obtido por via etanólica. Quimica Nova, 30(3), 600-603. https://doi.org/10.1590/S0100-40422007000300019

Lin, C.-H., Chen, Y.-K., \& Wang, W.-C. (2020). The production of bio-jet fuel from palm oil derived alkanes. Fuel, 260(July 2019), 116345. https://doi.org/10.1016/j.fuel.2019.116345

Liu, G., Yan, B., \& Chen, G. (2013). Technical review on jet fuel production. Renewable and Sustainable Energy Reviews, 25, 59-70. https://doi.org/10.1016/j.rser.2013.03.025

Llamas, A., Al-Lal, A. M., Hernandez, M., Lapuerta, M., \& Canoira, L. (2012). Biokerosene from babassu and camelina oils: Production and properties of their blends with fossil kerosene. Energy and Fuels, 26(9), 5968-5976. https://doi.org/10.1021/ef300927q

Llamas, A., García-Martínez, M. J., Al-Lal, A. M., Canoira, L., \& Lapuerta, M. (2012). Biokerosene from coconut and palm kernel oils: Production and properties of their blends with fossil kerosene. Fuel, 102, 483-490. https://doi.org/10.1016/j.fuel.2012.06.108

Lu, Y., Pan, J., Fan, B., Otchere, P., Chen, W., \& Cheng, B. (2020). Research on the application of aviation kerosene in a direct injection rotary engine - Part 2: Spray combustion characteristics and combustion process under optimized injection strategies. Energy Conversion and Management, 203(October 2019), 112217. https://doi.org/10.1016/j.enconman.2019.112217

Mahmudul, H. M., Hagos, F. Y., Mamat, R., Adam, A. A., Ishak, W. F. W., \& Alenezi, R. (2017). Production , characterization and performance of biodiesel 
as an alternative fuel in diesel engines - A review. Renewable and Sustainable Energy Reviews, 72(April 2016), 497-509. https://doi.org/10.1016/j.rser.2017.01.001

Marsh, G. (2008). Biofuels: aviation alternative? Renewable Energy Focus, 9(4), 48-51. https://doi.org/10.1016/S1471-0846(08)70138-0

Mcgrath, J. F., Goss, K. F., Brown, M. W., Bartle, J. R., \& Abadi, A. (2016). Aviation biofuel from integrated woody biomass in southern Australia. https://doi.org/10.1002/wene.221

Monirul, I. M., Kalam, M. A., Masjuki, H. H., Zulkifli, N. W. M., Shahir, S. A., Mosarof, M. H., \& Ruhul, A. M. (2017). Influence of poly(methyl acrylate) additive on cold flow properties of coconut biodiesel blends and exhaust gas emissions. Renewable Energy, 101, 702-712. https://doi.org/10.1016/j.renene.2016.09.020

Nie, G., Dai, Y., Liu, Y., Xie, J., Gong, S., Afzal, N., Zhang, X., Pan, L., \& Zou, J. J. (2019). High yield one-pot synthesis of high density and low freezing point jet-fuel-ranged blending from bio-derived phenol and cyclopentanol. Chemical Engineering Science, 207, 441-447. https://doi.org/10.1016/j.ces.2019.06.050

$\mathrm{N}^{\circ}$, R. A. N. P., \& Dou, D. E. (2009). Ranp 5 - 2009. 12.

Olcay H, Malina R, Upadhye AA, Hileman JI, Huber GW, B. S. (2018). Technoeconomic and environmental evaluation of producing chemicals and drop-in aviation biofuels via aqueous phase processing. Energy \& Environmental Science. https://doi.org/https:// doi.org/10.1039/C7EE03557H

Oliveira, L. E., Giordani, D. S., Paiva, E. M., De Castro, H. F., \& Da Silva, M. L. C. P. (2013). Kinetic and thermodynamic parameters of volatilization of biodiesel from babassu, palm oil and mineral diesel by thermogravimetric analysis (TG). Journal of Thermal Analysis and Calorimetry, 111(1), 155-160. https://doi.org/10.1007/s10973-011-2163-8

processamento-materias-primas-2019(1). (n.d.).

Ranucci, C. R., Alves, H. J., Monteiro, M. R., Kugelmeier, C. L., Bariccatti, R. A., Rodrigues de Oliveira, C., \& Antônio da Silva, E. (2018). Potential alternative aviation fuel from jatropha (Jatropha curcas L.), babassu (Orbignya phalerata) and palm kernel (Elaeis guineensis) as blends with Jet-A1 kerosene. Journal of Cleaner Production, 185, 860-869. https://doi.org/10.1016/j.jclepro.2018.03.084

Reimer, J., \& Zheng, X. (2016). Economic analysis of an aviation bioenergy supply chain. December. https://doi.org/10.1016/j.rser.2016.12.036

Rodrigues, J. D. A., Cardoso, F. D. P., Lachter, E. R., Estevão, L. R. M., Lima, E., \& Nascimento, R. S. V. (2006). Correlating chemical structure and physical properties of vegetable oil esters. JAOCS, Journal of the American Oil Chemists' Society, 83(4), 353-357. https://doi.org/10.1007/s11746-006-1212-0

Rodrigues Ranucci, C., José Alves, H., da Silva, C., Roberto Monteiro, M., Andressa dos Santos, K., Aparecido Bariccatti, R., \& Antonio da Silva, E. (2014). OBTENÇÃO DE BIOQUEROSENE DE PINHÃO-MANSO (JatrophacurcasL.) e suas misturas ao querosene fóssil obtaining biokerosene of jatropha (jatrophacurcasl.) and their mixtures to fossil kerosene. In Revista Tecnológica-Edição Especial.

Santos, J. R. De J; SOUZA, A. G. De; SILVA, F. C. (2008). BIODIESEL DE BABAÇU : Avaliação Térmica, Oxidativa e Misturas Binárias.

Santos, N. A., Tavares, M. L. A., Rosenhaim, R., Silva, F. C., Fernandes, V. J., Santos, I. M. G., \& Souza, A. G. (2007). Thermogravimetric and calorimetric evaluation of babassu biodiesel obtained by the methanol route. Journal of Thermal Analysis and Calorimetry, 87(3), 649-652. https://doi.org/10.1007/s10973-006-7765-1

Schäfer, A. W., \& Waitz, I. A. (2014). Air transportation and the environment. Transport Policy, 1-4. https://doi.org/10.1016/j.tranpol.2014.02.012

Silva, M. C. D., Da Silva, L. M., Santos, N. A., Conceição, M. M., Souza, A. G., \& Dos Santos, A. O. (2011). Study of ethylic Babassu biodiesel properties at low temperatures. Journal of Thermal Analysis and Calorimetry, 106(2), 363-367. https://doi.org/10.1007/s10973-011-1474-0

Simões, A. F., \& Schaeffer, R. (2005). The Brazilian air transportation sector in the context of global climate change: CO 2 emissions and mitigation alternatives. Energy Conversion and Management, 46(4), 501-513. https://doi.org/10.1016/j.enconman.2004.06.017

Verma, P., \& Sharma, M. P. (2016). Review of process parameters for biodiesel production from different feedstocks. Renewable and Sustainable Energy Reviews, 62, 1063-1071. https://doi.org/10.1016/j.rser.2016.04.054

Wang, W. C., \& Tao, L. (2016). Bio-jet fuel conversion technologies. Renewable and Sustainable Energy Reviews, 53, 801-822. https://doi.org/10.1016/j.rser.2015.09.016

Wilson, G. R., Edwards, T., Corporan, E., \& Freerks, R. L. (2013). Certification of alternative aviation fuels and blend components. Energy and Fuels, 27(2), 962-966. https://doi.org/10.1021/ef301888b

Yang, J., Xin, Z., He, Q. (Sophia), Corscadden, K., \& Niu, H. (2019). An overview on performance characteristics of bio-jet fuels. In Fuel (Vol. 237, pp. 916936). Elsevier Ltd. https://doi.org/10.1016/j.fuel.2018.10.079

Yilmaz, N., \& Atmanli, A. (2017). Sustainable alternative fuels in aviation. Energy, 140, 1378-1386. https://doi.org/10.1016/j.energy.2017.07.077

Yilmaz, N., \& Morton, B. (2011). Comparative characteristics of compression ignited engines operating on biodiesel produced from waste vegetable oil. Biomass and Bioenergy, 35(5), 2194-2199. https://doi.org/10.1016/j.biombioe.2011.02.032

Zalla, O., Neto, S., Gonçalves, D., Bergara, S. D. F., Augusto, E., Batista, C., José, A., \& Meirelles, D. A. (2019). Oil extraction from semi-defatted babassu bagasse with ethanol: Liquid-liquid equilibrium and solid-liquid extraction in a single stage. Journal of Food Engineering, 109845. https://doi.org/10.1016/j.jfoodeng.2019.109845

Zhang, C., Hui, X., Lin, Y., \& Sung, C. J. (2016). Recent development in studies of alternative jet fuel combustion: Progress, challenges, and opportunities. Renewable and Sustainable Energy Reviews, 54, 120-138. https://doi.org/10.1016/j.rser.2015.09.056 